\title{
Author Correction: Thermogenesis-triggered seed dispersal in dwarf mistletoe
}

\author{
Rolena A.J. deBruyn, Mark Paetkau, Kelly A. Ross, David V. Godfrey, John S. Church \& Cynthia Ross Friedman
}

Nature Communications 6:6262 doi: 10.1038/ncomms7262 (2015); Published 9 Feb 2015, Updated 25 Jun 2018

John S. Church, who provided access to the FLIR E60 infrared camera and provided guidance in its use, was inadvertently omitted from the author list in the originally published version of this Article. This has now been corrected in both the PDF and HTML versions of the Article.

\footnotetext{
(c) (i) Open Access This article is licensed under a Creative Commons Attribution 4.0 International License, which permits use, sharing, adaptation, distribution and reproduction in any medium or format, as long as you give appropriate credit to the original author(s) and the source, provide a link to the Creative Commons license, and indicate if changes were made. The images or other third party material in this article are included in the article's Creative Commons license, unless indicated otherwise in a credit line to the material. If material is not included in the article's Creative Commons license and your intended use is not permitted by statutory regulation or exceeds the permitted use, you will need to obtain permission directly from the copyright holder. To view a copy of this license, visit http://creativecommons.org/licenses/by/4.0/
}

(C) The Author(s) 2018 